\title{
HUBUNGAN VARIASI BAHASA DENGAN KELOMPOK SOSIAL DAN PEMAKAIAN BAHASA
}

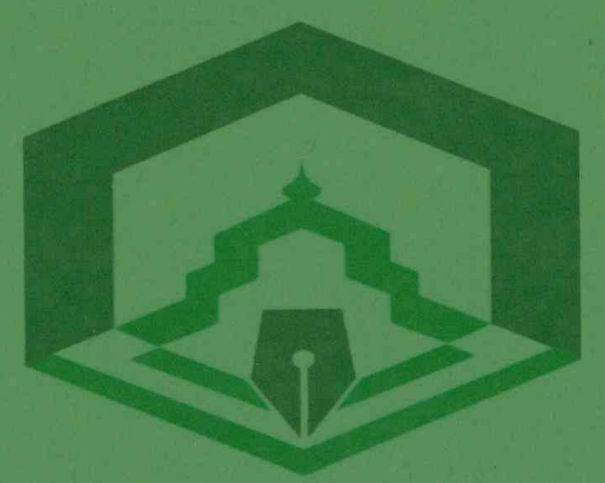

\section{IAIN PALOPO}

\author{
Ketua Tim ：Mirnawati, S.Pd, M.Pd \\ Sekertaris $\quad$ : Hisbullah, S.Pd, M.Pd \\ Anggota Tim : 1. Nur Salam/ Semester VIII \\ 2. Husaemah/ Semester VII \\ 3. Hasnawati/ Semester VII \\ INSTITUT AGAMA ISLAM NEGERI (IAIN) PALOPO \\ 2018
}




\section{SURAT TUGAS}

Nomor: 013 /In.19/FTIK/PP.00.9/09/2018

Dalam rangka Penelitian pengabdian kepada Masyarakat oleh Dosen PGMI, dengan Judul "Hubungan Variasi Bahasa Dengan Kelompok Sosial Dan Pemakaian Bahasa" maka Dekan FTIK memberi surat tugas kepada:

\begin{tabular}{|c|l|l|}
\hline NO & \multicolumn{1}{|c|}{ NAMA } & \multicolumn{1}{c|}{ JABATAN } \\
\hline 1 & Mirnawati S.Pd., M.Pd & Ketua Tim \\
\hline 2 & Hisbullah,S.Pd., M.Pd & Sekertaris \\
\hline 3 & Nur Salam & Pembantu Lapangan \\
\hline 4 & Husaemah & Pembantu Lapangan \\
\hline 5 & Hasnawati & Pengelolah Data \\
\hline
\end{tabular}

Untuk melaksanakan penelitian di Palopo pada hari Kamis, 02 Agustus 2018

Demikian, untuk dilaksanakan.






\title{
HUBUNGAN VARIASI BAHASA DENGAN KELOMPOK SOSIAL DAN PEMAKAIAN BAHASA
}

\begin{abstract}
ABSTRAK
Mempelajari sosiolinguistik berarti mempelajari bahasa dalam konteks sosio-kultural serta hubungan penutur dengan pendengarnnya. Kelompok sosial mengacu pada perbedaan penduduk atau kelompok dalam kelas-kelas kekuasaan, pendapatan, kedudukan, dan jenis pekerjaan. Melalui kajian sosiolinguistik kita dapat mengetahui variasi bahasa sekaligus kelompokkelompk/kelas-kelas sosial suatu masyarakat. Masyarakat bahasa terbentuk karena adanya saling pengertian, terutama karena adanya kebersamaan dalam kode-kode linguistik. Dalam pengertian masyarakat tersebut telah terkandung makna interaksi melalui komunikasi yaitu dengan bahasa. Sertifikasi sosial dalam suatu masyarakat menimbulkan ragam bahasa yang selanjutnya memperkokoh sertifikasi sosial. Sertifikasi ini sangat mempengaruhi pemilihan bahasa dalam tingkatan-tingkatan bahasa. Artinya, masyarakat kelas rendah mengalami rintangan atau hambatan dalam berkomunikasi karena kosakata tidak memadai/terbatas jika dibandingkan dengan kelompok sosial yang mempunyai kedudukan lebih tinggi.
\end{abstract}

kata kunci : variasi bahasa dalam kelompok sosial 


\section{PENDAHULUAN}

Sosiolinguistik adalah studi tentang karakteristik bahasa, karakteristik fungsifungsi bahasa, dan karakteristik pemakai bahasa terus-menerus perinteraksi satu sama lain dan mengalami perubahan di dalam masyarakat tuturnya. Sosio (sosial) berarti masyarakat, kelompok masyarakat, fenomena masyarakat, dan fungsi-fungsi masyarakat. Linguistik berkaitan dengan bahasa, misalnya fonem, morfem, kalimat, dan hubungan antara unsur-unsur bahasa tersebut.

Suwito (1983:4) mengatakan, sosiolinguistik adalah studi interdisipliner antara masalah-masalah kebahasaan dalam hubungannya dengan masalahmasalah sosial. David Crystal (1980:324) mengatakan, "sosiolinguistik adalah cabang linguistik yang mempelajari seluruh aspek relasi antara bahasa dan masyarakat." Nama lain untuk sosiolinguistik ialah sosiologi bahasa. Istilah sosiologi bahasa lebih menekankan aspek sosiologinya daripada aspek linguistiknya. Dilihat dari aspek penekanannya, keduaistilah ini mungkin ada perbedaan. Sosiolinguistik, cabang linguistik yang menghubungkan faktor bahasa dengan faktor sosial, sedangkan sosiologi bahasa merupakan cabang sosiologi yang menghubungkannya dengan faktor linguistik. Untuk lebih jelasnya perbedaan kedua istilah ini, Alwasilah (1985:3) mengatakan, "sosiologi bahasa membidangi faktor-faktor sosial dalam skala besar yang saling bertimbal-balik dengan bahasa dan dialek-dialek. Sosiolinguistik lebih berhubungan dengan perincianperincian (details of language) dalam penggunaan yang sebenarnya yang oleh Hymes disebut the ethnography of speaking." Ronald Wardahaugh (1986 : 12 -13) mengatakan bahwa sosiolinguistik menyangkut penelitian bahasa dengan masyarakat, memahami struktur bahasa dan fungsi bahasa dalam komunikasi, sedangkan sosiologi bahasa menyangkut penelitian antara bahasa dengan masyarakat dan memahami struktur social 
melalui studi bahasa. Hudson (1980: 4-5) melihat perbedaan istilah itu pada hubungan kedua istilah itu dengan objeknya.

Samsuri (1988:2) mengatakan, sosiolinguistik adalah kajian yang melibatkan lingkungan sosial.Sosiolinguistik memandang bahasa pertama-tama sebagai sistem sosial dan sistem komunikasi serta merupakan bagian dari masyarakat dan kebudayaan tertentu, (Suwito; 1983 : 5). Mempelajari sosiolinguistik berarti mempelajari bahasa dalam kontek sosiokultural serta hubungan penutur dengan pendengarnya. Dengan demikian dalam sosiolinguistik akan dibicarakan :

1. mengkaji bahasa dalam konteks sosial dan kebudayaan,

2. menghubungkan faktor-faktor kebahasaan, ciri-ciri, dan ragam bahasa dengan situasi serta faktor-faktor sosial dan budaya,

3. mengkaji fungsi-fungsi sosial dan penggunaan bahasa dalam masyarakat (Nababan,

1986:3)Pateda (1987:5-6) membagi sosiolinguistik atas dua bagian yaitu :

1. mikro sosiolinguistik yang berhubungan dengan kelompok kecil,

2. makro sosiolinguistik yang berhubungan dengan masalah perilaku bahasa dan struktur social

Selanjutnya dia mengatakan persoalan pokok sosiolinguistik ialah :

a. tentang profil sosiolinguistik, yaitu bagaimana keanekaragaman bahasa mencerminkan keanekaragaman sosial yang biasanya bersifat statistik.

b. dinamika sosiolinguistika yang diusahakan dengan mencari ciri-cirinya terhadap

berbagai jenis situasi sosiolinguistik yang mencakup :

- bidang pemakaian, situasi yang menyebabkan adanya pengalihan pembicaraan (variety switching)

- sikap bahasa, baik terhadap bahasa sendiri maupun yang bukan bahasa ibu - proses-proses sosiolinguistik yang berhubungan dengan mekanisme yang menimbulkan berbagai jenis situasi sosiolinguistik, misalnya : 
(pendidikan akademik). Perbedaan ini terutama terlihat pada penggunaan struktur dan pilihan kosa kata yang digunakannya pada waktu berinteraksi. Penggunaan kosa kata dalam kaitannya dengan tingkat pendidikan ini biasanya erat hubungannya dengan disiplin ilmu atau profesi penutur bahasa itu. Seorang dokter akan lebih sering menggunakan kata-kata bidang kedokteran. Seorang insinyur mesin akan banyak menggunakan kata bidang permisinan. Seorang guru akan banyak menggunakan istilah keguruan dan pendidikan.

Berdasarkan uraian di atas dapat ditarik kesimpulan, bahwa bahasa dengan segala

variasinya berhubungan dengan kelas sosial suatu masyarakat. Namun muncul sebuah pertanyaan "Bahasakah yang menyebabkan adanya kelas sosial dalam suatu masyarakat

atau kelas sosialkah yang menyebabkan adanya variasi bahasa?"

\section{KESIMPULAN}

Sosiolinguistik adalah ilmu interdisipliner, karena sosiolinguistik dalam kajiannya tidak dapat dilepaskan dari disiplin ilmu yang lain yaitu sosiologi. Sebagai ilmu antar disiplin, sosiolinguistik sangat bermakna jika dikaji dengan teliti dan seksama. Melalui kajian sosiolinguistik kita dapat mengetahui variasi bahasa dan sekaligus kelompok-kelompok sosial suatu masyarakat. 